ISSN 2227-9717

www.mdpi.com/journal/processes

Article

\title{
Design, Operation, Control, and Economics of a Photovoltaic/Fuel Cell/Battery Hybrid Renewable Energy System for Automotive Applications
}

\author{
Zachary S. Whiteman ${ }^{1}$, Piyush Bubna ${ }^{2}$, Ajay K. Prasad ${ }^{2}$ and Babatunde A. Ogunnaike 1,* \\ 1 Department of Chemical and Biomolecular Engineering, University of Delaware, Newark, \\ DE 19711, USA; E-Mail: uka1188@gmail.com \\ 2 Department of Mechanical Engineering, University of Delaware, Newark, DE 19711, USA; \\ E-Mails: pbubna@gmail.com (P.B.); prasad@udel.edu (A.K.P.) \\ * Author to whom correspondence should be addressed; E-Mail: ogunnaike@udel.edu; \\ Tel.: +1-302-831-8017.
}

Academic Editor: Michael Henson

Received: 17 May 2015 / Accepted: 3 June 2015 / Published: 9 June 2015

\begin{abstract}
Meeting rapidly growing global energy demand-without producing greenhouse gases or further diminishing the availability of non-renewable resources-requires the development of affordable low-emission renewable energy systems. Here, we develop a hybrid renewable energy system (HRES) for automotive applications-specifically, a roof-installed photovoltaic (PV) array combined with a PEM fuel cell/NiCd battery bus currently operating shuttle routes on the University of Delaware campus. The system's overall operating objectives - meeting the total power demand of the bus and maintaining the desired state of charge (SOC) of the NiCd battery-are achieved with appropriately designed controllers: a logic-based "algebraic controller" and a standard PI controller. The design, implementation, and performance of the hybrid system are demonstrated via simulation of real shuttle runs under various operating conditions. The results show that both control strategies perform equally well in enabling the HRES to meet its objectives under typical operating conditions, and under sudden cloud cover conditions; however, at consistently high bus speeds, battery SOC maintenance is better, and the system consumes less hydrogen, with PI control. An economic analysis of the PV investment necessary to realize the HRES design objectives indicates a return on investment of approximately $30 \%$ (a slight, but nonetheless positive, $\sim \$ 550$ profit over the bus lifetime) in Newark, DE,
\end{abstract}


establishing the economic viability of the proposed addition of a PV array to the existing University of Delaware fuel cell/battery bus.

Keywords: hybrid renewable energy system; fuel cell bus; PI control; photovoltaic; PEM fuel cell; NiCd battery; hydrogen; economic analysis

\section{Introduction}

The use of internal combustion engines (ICEs) to power vehicles has become so widely recognized as unsustainable and environmentally hazardous as to spur the development of cost-effective and reliable alternatives, including renewable energy systems for automotive applications. For such applications, proton exchange membrane fuel cells (PEMFCs) have some inherent advantages over ICEs. For example, many PEMFC-powered vehicles are more than twice as thermodynamically efficient as ICE-powered vehicles, while emitting zero greenhouse gases [1]. Furthermore, PEMFCs have fewer moving parts than ICEs, making them more reliable and less noisy [2]. Despite such advantages, the automotive industry has not been as receptive to PEMFCs, for two reasons: higher manufacturing cost $(\sim \$ 3000 / \mathrm{kW}$ vs. $\sim \$ 50 / \mathrm{kW}[3])$, and lower vehicle accelerating potential (i.e., specific power) $(\sim 100 \mathrm{~W} / \mathrm{kg} v s$. $\sim 1000 \mathrm{~W} / \mathrm{kg}$ [4]), which jointly make stand-alone PEMFCs impractical in automotive applications. Such shortcomings may be mitigated by judiciously combining a PEMFC with one or more complementary renewable energy systems to form a hybrid renewable energy system (HRES) - a system consisting of two or more individual renewable energy systems utilized simultaneously to meet an energy demand.

At the University of Delaware, a HRES shuttle bus consisting of a PEMFC and a nickel-cadmium (NiCd) battery (Figure 1) was recently incorporated into the university's shuttle bus fleet [5]. The NiCd battery is used to meet the bus's power demand while the hydrogen-fueled PEMFC is used to maintain the NiCd battery's state of charge (SOC) at a desired value. Because a NiCd battery is less expensive than a PEMFC $(\sim \$ 300 / \mathrm{kW} \quad v s . \sim \$ 3000 / \mathrm{kW} \quad[6])$ and has a higher accelerating potential $(\sim 250 \mathrm{~W} / \mathrm{kg} v s . \sim 100 \mathrm{~W} / \mathrm{kg}[4])$, the HRES design provides a cheaper and more effective alternative to a stand-alone PEMFC-powered bus.

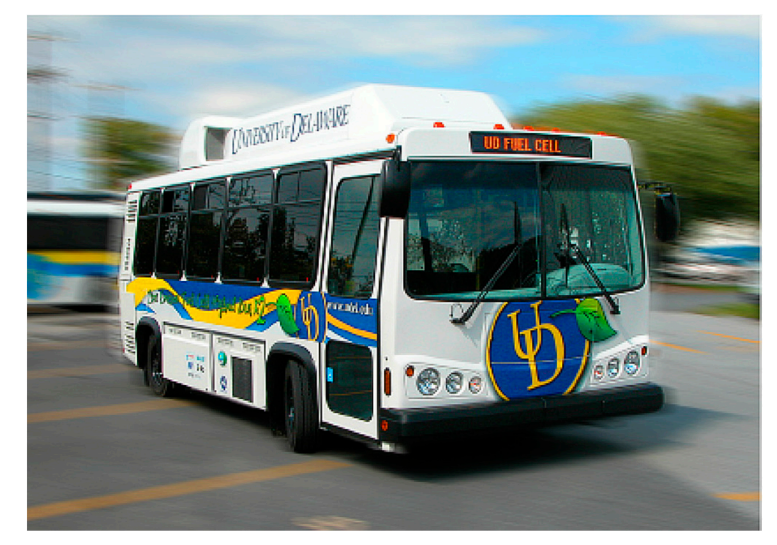

Figure 1. The University of Delaware's 22-foot, 22-seat transit bus equipped with a fuel cell/battery series-hybrid powertrain, manufactured by EBus, Inc. of Downey, CA, USA. 
Although a fuel cell/battery bus offers a viable "no emissions" alternative for automotive applications, it remains more expensive than traditional buses powered by ICEs. Operating costs can be reduced further, without increasing greenhouse gas emissions, by incorporating a roof-installed PV array into the current design. The additional power produced by the PV array can be used to supplement the battery in meeting the bus's power demand, and the fuel cell in charging the battery. Reducing the power needed from the fuel cell to maintain battery SOC results in a commensurate reduction in the use of hydrogen, which translates to a direct reduction in operating cost.

Whether augmented with a PV array or not, the operating objectives of the fuel cell/battery-powered bus are two-fold: (1) satisfy bus power demand instantly, at all time; and (2) maintain the NiCd battery SOC at $65 \%$ (SOC values much lower than $65 \%$ impair the battery's ability to supply required power during periods of high demand (such as rapid acceleration event or hill climbing), whereas with SOC values much higher than $65 \%$, the battery may not be able to accept the entire amount of power generated from regenerative braking.). These objectives are challenging to meet in practice primarily because of rapid changes in desired bus speed (i.e., bus power demand) during a typical campus shuttle run characterized by frequent starts and stops. When the bus is augmented with a PV array, one must now contend, in addition, with the unpredictable variability in available PV power. The consequences of not handling these challenges adequately are (1) overuse or underuse of the battery in meeting the power demand; and (2) deep battery discharge $(<20 \%$ SOC) or battery overcharging $(>80 \%$ SOC) [7], the latter condition being undesirable because it initiates oxygen-producing side reactions in the battery, which can reduce the battery's operating lifetime [8]. Because these challenges may be met with appropriately designed control systems, one of our goals is to design and evaluate control strategies that will enable the PV/fuel cell/battery HRES to satisfy the bus's power demand while maintaining the battery SOC at $65 \%$, in spite of rapid fluctuations in bus power demand and PV power.

Two classes of methods have been previously reported for controlling fuel cell hybrid electric vehicles: rule-based methods and optimization methods. Rule-based methods use a set of pre-defined logical statements to control the vehicle given current operating conditions and desired set points. Because they are simple, such methods are computationally efficient and relatively cheap to implement, but have been shown to provide adequate power demand and battery SOC control while reducing hydrogen consumption [9-14]. In contrast, the second class of methods, which determine control action via optimization, have been shown to provide better overall performance (improved power demand and battery SOC control, and reduced hydrogen consumption) than rule-based methods [15-23]. However, optimization methods, such as those that employ dynamic programming or Pontryagin's Minimum Principle, require a priori knowledge of the vehicle drive cycle, rendering them sub-optimal under unusual or unexpected driving conditions (e.g., hill climbing, lane changing, and abrupt starts and stops); furthermore, because of inherent complexity, these methods are computationally expensive and hence subject to high implementation costs.

In this paper, we consider two separate control strategies: an "algebraic" control strategy (currently used on the bus [5]) and standard proportional-integral (PI) control. These control strategies retain the simplicity and computational efficiency of rule-based methods, while employing instantaneous system information without requiring a priori knowledge of the drive cycle. As discussed shortly, the "algebraic" control strategy is so-called because it consists of algebraic expressions for determining, based on straightforward logic, the appropriate control action (battery power request and fuel cell power 
request) needed to meet the bus's operating objectives. The original algebraic control strategy was designed specifically to enable the fuel cell/battery HRES meet bus operating objectives under normal operating conditions only (i.e., during typical shuttle runs). Although the strategy can be extended to include PV power as well, such a control strategy may not be effective in enabling the bus meet its operating objectives under other operating conditions (e.g., sustained increase in bus speed) that are not represented in the simple logic behind the algebraic controller equations.

Finally, since the addition of a PV array to the fuel cell/battery involves initial investment costs, it is necessary to determine if the resulting reduction in operating costs is worth the investment. The standard economic metric of "return on investment" (ROI), is determined in this case from the following expression:

$$
R O I=100\left(\frac{\left[365 L_{b u s} A_{b u s} C_{H_{2}}\left(M_{H_{2}, n o P V}-M_{H_{2}, P V}\right)\right]-C_{P V}}{C_{P V}}\right)
$$

The numerator consists of the net difference in lifetime operating costs accruing from the PV array installation, minus the cost of the PV array (including installation). All indicated terms are fixed constants, with the exception of $M_{H_{2}, n o P V}$, the daily mass of hydrogen consumed by the bus without a PV array, and $M_{H_{2}, P V}$, the equivalent daily consumption with an incorporated PV array, both functions of the average solar irradiance during periods of bus operation $\left(G_{T, a v g}\right), \mathrm{PV}$ array size $\left(S_{P V}\right)$, and PV array efficiency $\left(\eta_{P V}\right)$. Thus, ROI will vary as a function of these three parameters, and therefore an additional goal is to determine the values of $G_{T, a v g}, S_{P V}$, and $\eta_{P V}$ required for positive ROI.

The remainder of this paper is organized as follows: in Section 2 we describe the PV/fuel cell/battery hybrid process, and the HRES simulation model. Section 3 is devoted to the design of the two control strategies, whose performances are evaluated via simulation and discussed in Section 4. The economics of incorporating a roof-installed PV array into the existing fuel cell/battery bus design is analyzed and discussed in Section 5, followed by a summary of the results and important conclusions in Section 6.

\section{The Process: Component Description, Modeling, and Simulation}

The process under investigation, shown schematically in Figure 2, is a PV/fuel cell/battery HRES employed in a bus. It consists of four primary components: a NiCd battery, a PEMFC system, a PV array, and a traction motor. The majority of the bus's power demand is to be satisfied by the $120 \mathrm{~kW}$-rated SAFT NiCd battery. The battery is charged primarily by the $32 \mathrm{~kW}$-rated PEMFC system, which consists of two Ballard Mark9 SSL PEMFCs. The $2.4 \mathrm{~kW}$-rated (The PV array rated power output is the power output under standard test conditions $\left(G_{T}=1000 \mathrm{~W} / \mathrm{m}^{2}\right.$, a PV module temperature of $25^{\circ} \mathrm{C}$, and a solar spectrum irradiance of AM 1.5).) PV array, consisting of eight LG300N1C-G3 monocrystalline silicon modules that will cover most of the roof of the bus $\left(\sim 15 \mathrm{~m}^{2}\right)$, is to be used to supplement the battery output in meeting the bus's power demand, and to assist the fuel cell in charging the battery. A three-phase alternating current (AC) induction traction motor is responsible for converting electrical energy from the battery or the PV array to the mechanical energy that moves the bus. The traction motor has regenerative braking capability, producing electricity to charge the battery as the bus decelerates.

The PEMFC operation is facilitated by four auxiliary components: twin high-pressure hydrogen storage tanks, a scroll-type air compressor, a fan-cooled radiator, and a membrane humidifier. The high-pressure hydrogen storage tanks, each rated at 350 bar, can store up to $6.4 \mathrm{~kg}$ of hydrogen. 
The stored hydrogen is released to the anode of the PEMFC system via a pressure regulator valve, while oxygen is delivered to the cathode of the PEMFC system via a scroll-type air compressor. The temperature of the fuel-cell system is maintained at $70{ }^{\circ} \mathrm{C}$ using a low-conductivity ethylene glycol/water mixture and a fan-cooled radiator. A membrane humidifier maintains relative humidity of the compressed air at $100 \%$ using moisture from the cathode exhaust air.

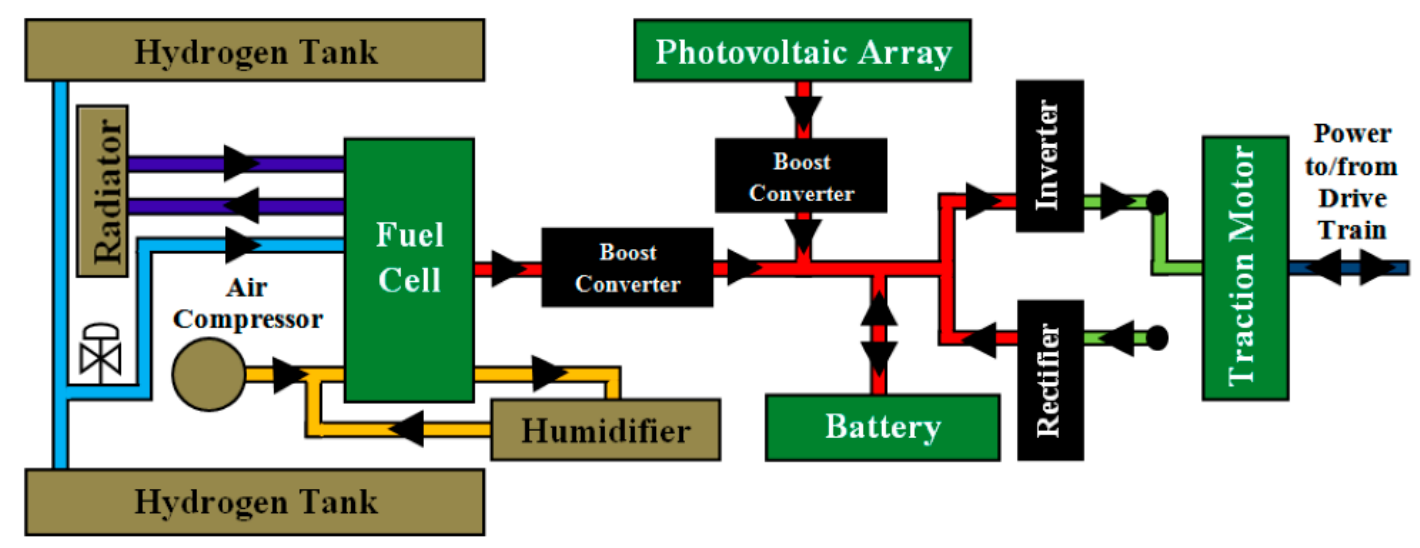

Figure 2. Schematic diagram of the UD fuel cell bus's PV/PEM fuel cell/NiCd battery hybrid power train. Color legends: (1) Blocks: green, primary components; beige, auxiliary fuel cell components; black, power conditioning units; and (2) Streams: purple, glycol/water mixture; light blue, hydrogen; yellow, air; red, DC power; light green, AC power; dark blue, mechanical power to/from the drive train. Black arrows indicate stream flow direction.

The power conditioning units on the bus (used to match the voltage and current type of an electrical power source with an electrical power sink) consist of two boost converters, an inverter, and a rectifier. Each boost converter increases the low voltage direct current (DC) power ( $\sim 75 \mathrm{~V}$ for the fuel cell and $\sim 30 \mathrm{~V}$ for the PV array) to match the high voltage DC power of the main DC bus $(\sim 300 \mathrm{~V})$. The inverter is used to convert DC power from the main DC bus to three-phase AC power usable by the traction motor, while the rectifier converts three-phase AC power from regenerating braking to DC power usable by the battery.

Each component module is modeled mathematically and connected appropriately in Simulink to simulate the entire process. The battery, fuel cell, and traction motor models used here are described in reference [24]. Time delays due to hydrogen transport and fuel cell activation were not included in the fuel cell model because previous work has shown that simulation fidelity is not affected significantly by whether these delays are represented explicitly or not [23]. However, the dynamic lag between requested fuel cell power and actual fuel cell power delivered, which is important to performance, is incorporated in the form of a first order transfer function with a steady-state gain of 1 and time constant, $5.5 \mathrm{~s}$. while the PV array model is based on reference [25]. All parameter values used in the PV array model are identical to those in [25] with the exception of the ideality factor $(A)$, the short-circuit current temperature coefficient $\left(K_{i}\right)$, and the short-circuit current under standard test conditions $\left(I_{s c r}\right)$, whose values were changed from the published $1.6,0.0017 \mathrm{~A} /{ }^{\circ} \mathrm{C}$, and $3.21 \mathrm{~A}$, to $1.3,0.003 \mathrm{~A} /{ }^{\circ} \mathrm{C}$, and $10 \mathrm{~A}$, respectively, to be consistent with the characteristics of the PV array considered here. 


\section{Control Strategies}

\subsection{Control System Configuration}

The primary operating objectives of the PV/fuel cell/battery bus are to satisfy the required power demand at all times and to maintain the battery SOC at $65 \%$. Meeting these objectives requires that the combined power output from the battery and from the PV array match the power demand, while simultaneously maintaining the battery SOC at the desired value. Consequently, the controlled variables (CVs) for this system are (i) the total system power output $\left(P_{\text {output }}\right)$; and (ii) the measured battery SOC $\left(S O C_{m}\right)$. The manipulated variables (MVs) available for achieving the objectives are (i) the power requested from the battery $\left(P_{b a t t, \text { request }}\right)$; and (ii) the power requested from the fuel cell $\left(P_{F C \text {,request }}\right)$ to charge the battery. (It is important to distinguish the requested power from the actual power output because of the dynamics involved in delivering requested power by each of these devices.) The power produced by the PV array $\left(P_{P V}\right)$, and that produced from regenerative braking $\left(P_{R B}\right)$ are considered disturbance variables (DVs) since they affect the CVs but cannot be manipulated at will.

Control strategies are to be designed to use the two available MVs to maintain the two CVs at their respective desired set points in spite of uncontrollable fluctuations in the DVs. Such a $2 \times 2$ system is, by definition, a multivariable system which may require multivariable control strategies to achieve effective control [26]. However, in this case, the physical characteristics of the process indicate clearly that the simple strategy of employing two separate control loops, where one MV is paired with one CV, may actually suffice. This is because, first, the appropriate pairing is obvious and straightforward: $P_{b a t t, r e q u e s t}$ should be used to control power output, and $P_{F C \text {,request }}$ should be used to control battery SOC; second, there will be minimal interaction between the two loops. Table 1 shows the two-single-loops control system configuration, along with the CVs, CV set points, MVs, and DVs.

Table 1. PV/fuel cell/battery HRES process variables and control loop configuration.

\begin{tabular}{ccccc}
\hline Control loop & $\begin{array}{c}\text { Manipulated variable } \\
(\mathbf{M V})\end{array}$ & $\begin{array}{c}\text { Controlled } \\
\text { variable }(\mathbf{C V})\end{array}$ & CV setpoints & $\begin{array}{c}\text { Disturbance variables } \\
\text { (DVs) }\end{array}$ \\
\hline 1 & $P_{\text {batt,request }}$ & $P_{\text {output }}$ & $P_{\text {total }}$ & $P_{P V}$ \\
2 & $P_{F C, \text { request }}$ & $S O C_{m}$ & $S O C_{d}$ & $P_{P V, \text { excess }}$ and $P_{R B}$ \\
\hline
\end{tabular}

We now consider the design of two distinct control strategies to be used to implement the indicated control configuration.

\subsection{Algebraic Control Strategy}

This control strategy [5] consists of two separate control loops configured as shown in Figure 3; it is so-named because each controller is based on algebraic equations. Controller 1, which is responsible for meeting the bus power demand, is based on the straightforward logic that the total power output to the bus is the sum of what the battery discharges and what is produced by the PV array, i.e.,

$$
P_{\text {total }}=P_{\text {batt }, \text { dis }}+P_{P V}
$$




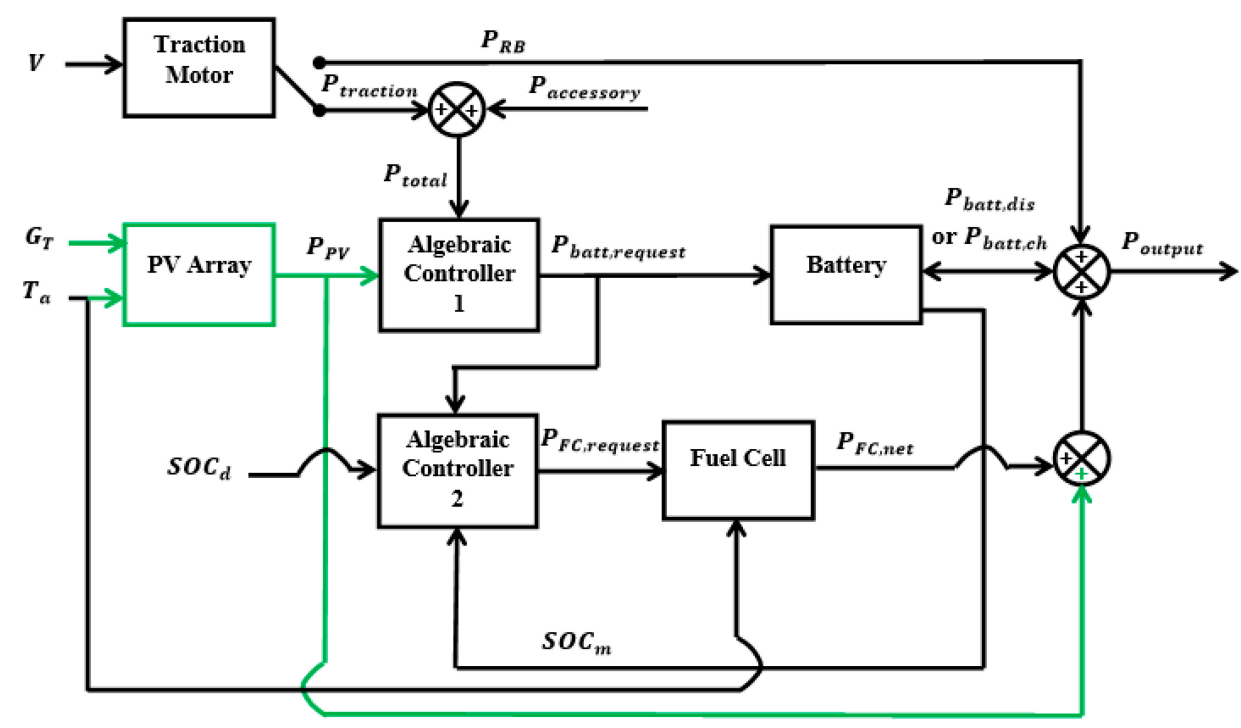

Figure 3. Control block diagram of the PV/fuel cell/battery HRES under the "algebraic control" strategy. Black blocks and lines indicate components of the original control scheme [5]; green blocks and lines indicate modifications to the original control scheme introduced to accommodate the added PV array.

Consequently, the power needed from the battery in order to meet the power demand is only what is required to augment the PV array output; that is, the appropriate $P_{\text {batt,request }}$, is the difference between the desired power, $P_{\text {total }}$, (which is pre-specified), and $P_{P V}$, which is uncontrolled: i.e.,

$$
P_{\text {batt, request }}=P_{\text {total }}-P_{P V}
$$

Observe that this expression, even though logical, ignores the transient dynamics between $P_{\text {batt,request }}$ and the battery discharge power $\left(P_{\text {batt,dis }}\right)$. Consequently, when transients are significant, this control strategy is expected to lose some performance.

Controller 2, which is responsible for maintaining battery SOC, uses the following algebraic equation to determine the value of $P_{F C \text {,request }}$ needed to maintain the battery SOC at $65 \%$ :

$$
P_{F C, \text { request }}=\left\{\begin{array}{c}
\beta\left(S O C_{d}-S O C_{m}\right)+P_{a v g}-P_{P V, \text { excess }}, P_{P V}>P_{\text {total }} \\
\beta\left(S O C_{d}-S O C_{m}\right)+P_{a v g}, P_{P V} \leq P_{\text {total }}
\end{array}\right.
$$

where $\beta$ is a proportionality constant (The appropriate value for $\beta$ is determined from the battery power capacity $(60,000 \mathrm{Wh})$ divided by the desired battery recharge time (changed from the value of $0.75 \mathrm{~h}$ in the original publication [5] to $0.2 \mathrm{~h}$ here in order to accommodate the corresponding change in $S O C_{d}$ from $55 \%$ to $65 \%$ ), and by 100 (to convert from W to W/\%) [5].) $(3000 \mathrm{~W} / \%)$ and $P_{\text {avg }}$ is the one-hour time average net power of the battery. Equation (3a) is used when $P_{P V}$ exceeds $P_{\text {total }}$, in which case the excess power from the $\mathrm{PV}$ array, $P_{P V \text {,excess }}$, is available to use to charge the battery - for example, during deceleration on a sunny day. Otherwise Equation (3b) is used to calculate $P_{F C \text {,request }}$, as discussed in [5]. 


\subsection{PI Control Strategy}

A control block diagram of the PI control strategy for the PV/fuel cell/battery HRES is shown in Figure 4. In control loop $1, P_{\text {batt,request }}$ is determined from $\varepsilon_{1}$, the feedback error between desired power set point and actual measured output, using the classical proportional-integral (PI) algorithm:

$$
P_{\text {batt,request }}=K_{p 1} \varepsilon_{1}+K_{i} \int_{0}^{t} \varepsilon_{1}(\tau) d \tau
$$

Here $K_{p 1}$ and $K_{i}$ are, respectively, the proportional gain (specific value for the simulation, 2.67), and integral gain (specific value, 16.83) of the total power controller. We opt for the PI controller instead of the PID controller because bus speed data (and hence bus power demand signal) can be extremely noisy, a condition that is not conducive to the application of derivative action because the derivative of a noisy $\varepsilon_{1}$ amplifies the noise further, leading to excessive and unnecessary fluctuations in control action and inevitable poor performance [26]. In control loop 2, $P_{F C \text {,request }}$ is determined from $\varepsilon_{2}$, the feedback error between desired state of charge and actual measured value, using a proportional-only (P-only) algorithm:

$$
P_{F C \text {,request }}=K_{p 2} \varepsilon_{2}
$$

Here $K_{p 2}$ is the proportional gain of the battery SOC controller (30,000 W/\%). A P-only controller suffices for battery SOC control because a step increase in $P_{F C \text {,request }}$ results in a ramp increase in $S O C_{m}$, in which case, the "controlled process" is recognized as a pure integrator, which does not require a controller with integral action in order to obtain offset-free control [26].

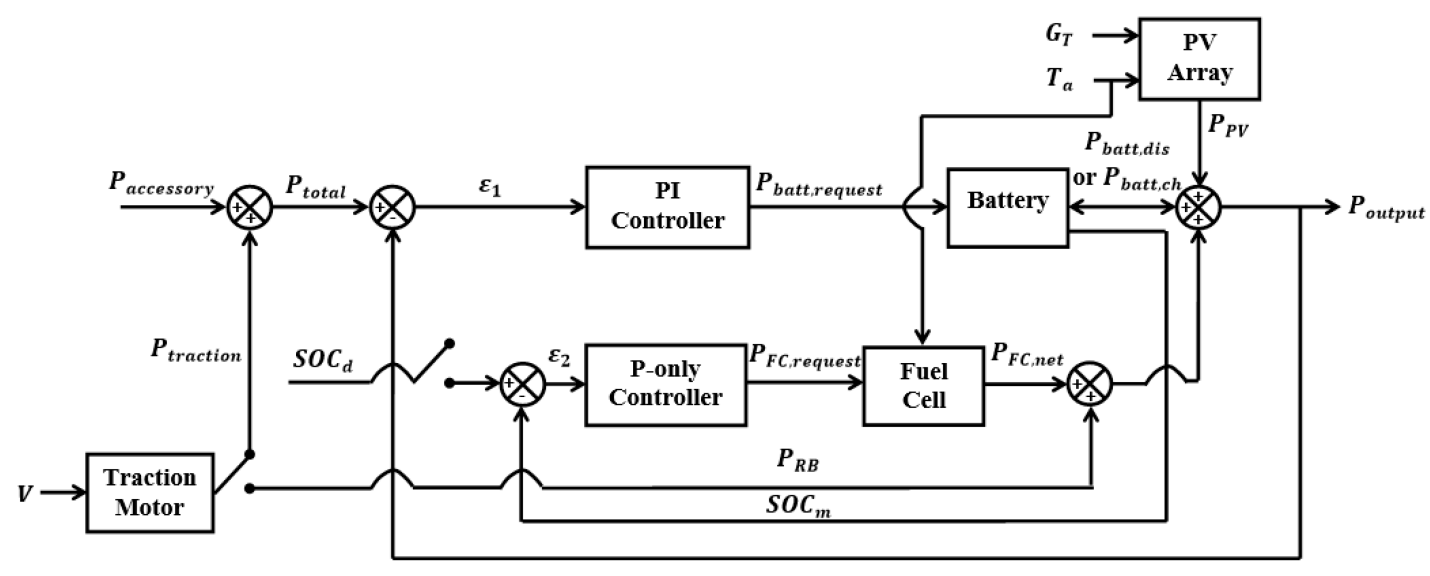

Figure 4. Control block diagram of the PV/fuel cell/ battery HRES under PI control. Control loop 1 uses a PI controller to control total power output by manipulating $P_{\text {batt,request }}$; Control loop 2 uses a P-only controller to control battery state of charge by manipulating $P_{F C \text {,request }}$. 


\section{Control Strategy Performance Evaluation}

The performance and effectiveness of the algebraic and PI control strategies in achieving the stated operating objectives are evaluated via simulation (supplemented with real data), under three separate operating conditions:

(1) Typical operating conditions (solar irradiance, vehicle speed, and ambient temperature) during summer and winter.

(2) Conditions of sudden changes in cloud cover.

(3) Conditions of sustained increase in bus speed.

We assume that:

(1) Each PV array module is exposed to the same solar irradiance and ambient temperature.

(2) The DC/DC converters, the inverter, and the rectifier operate at steady state, and at $90 \%$ efficiency.

(3) The battery is fully charged at the beginning of each simulation.

(4) The accessory power demand is constant at $3 \mathrm{~kW}$.

\subsection{Typical Operating Conditions}

To evaluate the performance of the algebraic and PI control strategies during typical operation in summer and winter, the bus operation is simulated using real solar irradiance (Figure 5a), bus speed (Figure 5b), and ambient temperature data over the indicated period. Solar irradiance measurements are obtained at half second intervals while the bus is driven on its typical shuttle route (the UD express route) between 12:00 p.m. and 3:40 p.m., using an SP-215 Apogee pyranometer installed on the roof of the bus. (The summer data were acquired on 15 July 2011; the winter data on 15 January 2012.) The bus speed is measured with an onboard GPS device. The summer and winter ambient temperatures are set as $301.24 \mathrm{~K}$ and $270.23 \mathrm{~K}$, respectively, the averages of hourly temperature data collected in Wilmington, DE, by meteorologists at the New Castle County Airport between 12:00 p.m. and 4:00 p.m. on 15 July 2011 and 15 January 2012.
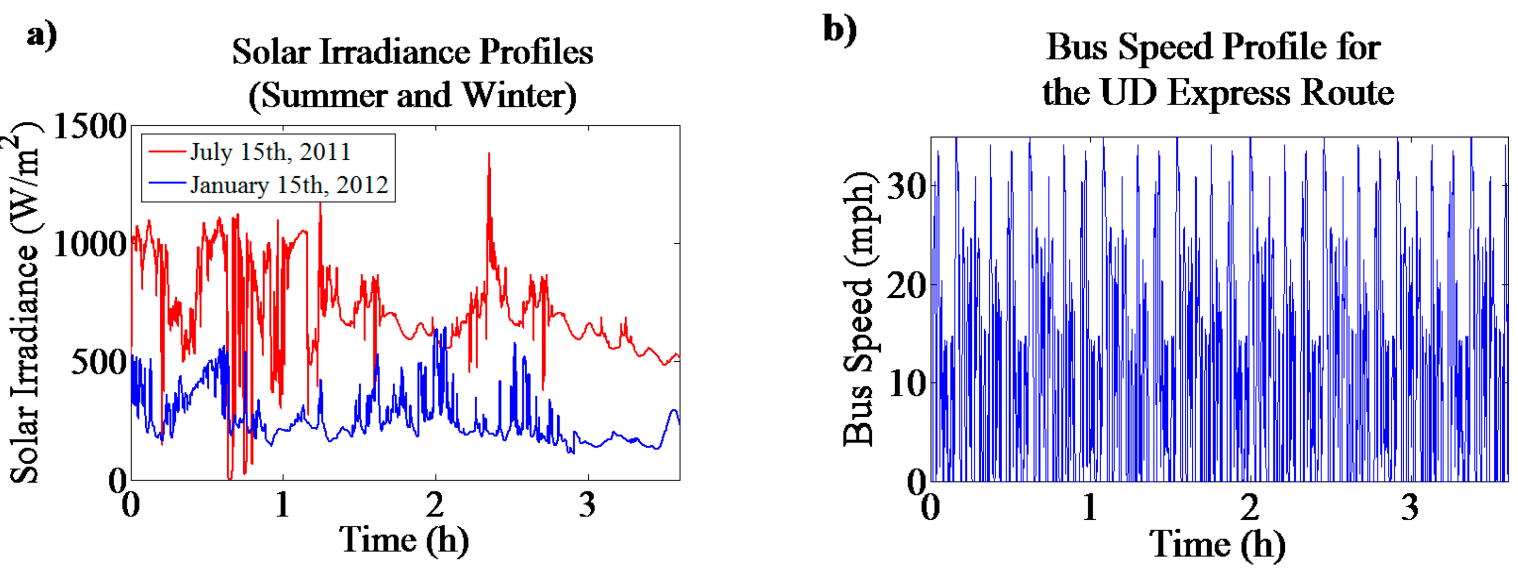

Figure 5. (a) Actual solar irradiance data used to simulate bus operation with a roof-installed PV array, during the summer (red), and winter (blue). (b) Actual bus speed data used to simulate typical bus traction power demands. 

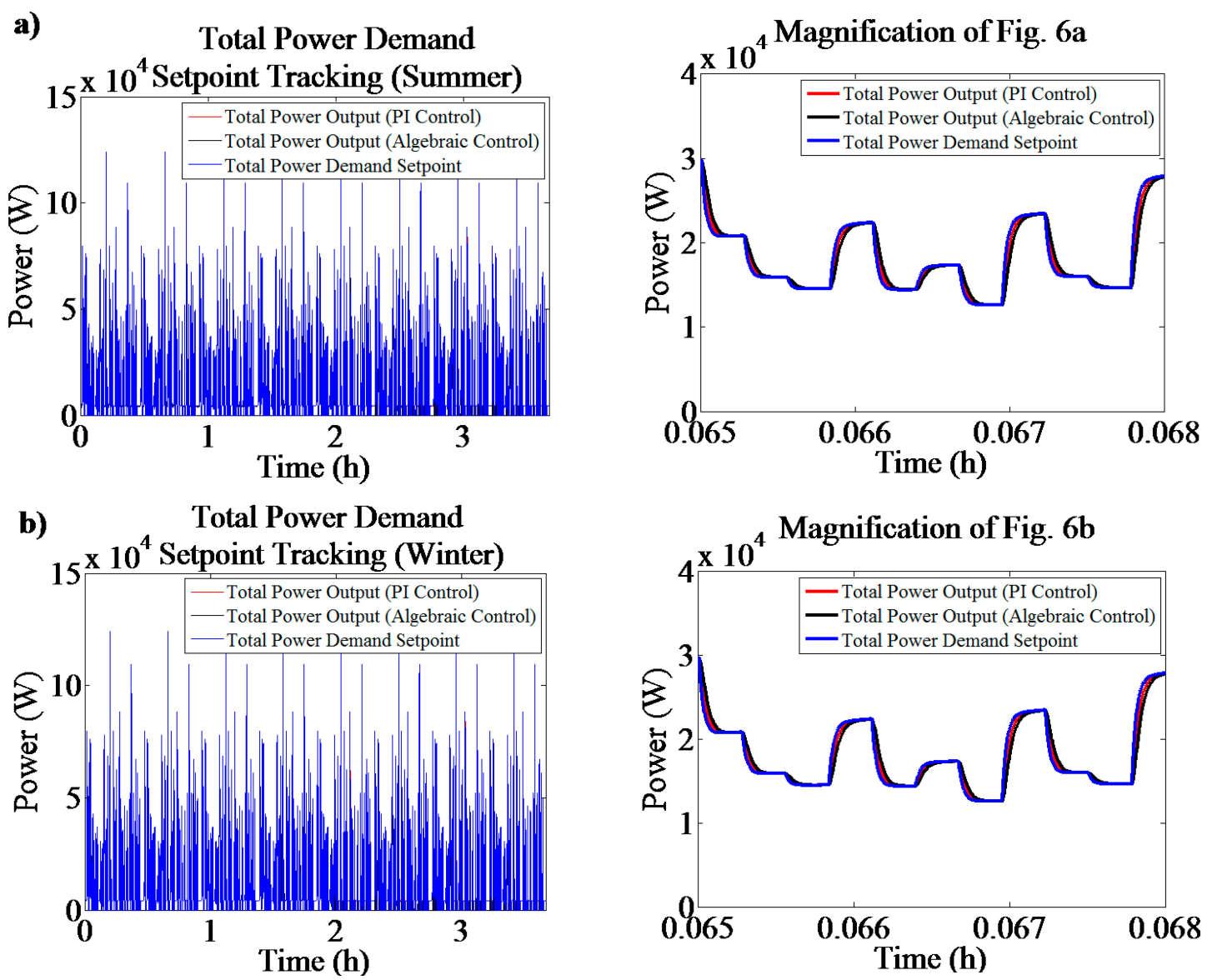

Figure 6. Total power demand set point tracking for the bus using the algebraic and PI control strategies: (a) summer operation and (b) winter operation. The magnified plots show details of controller performance, how rapid changes in bus speed (hence power demands) were tracked reasonably well.
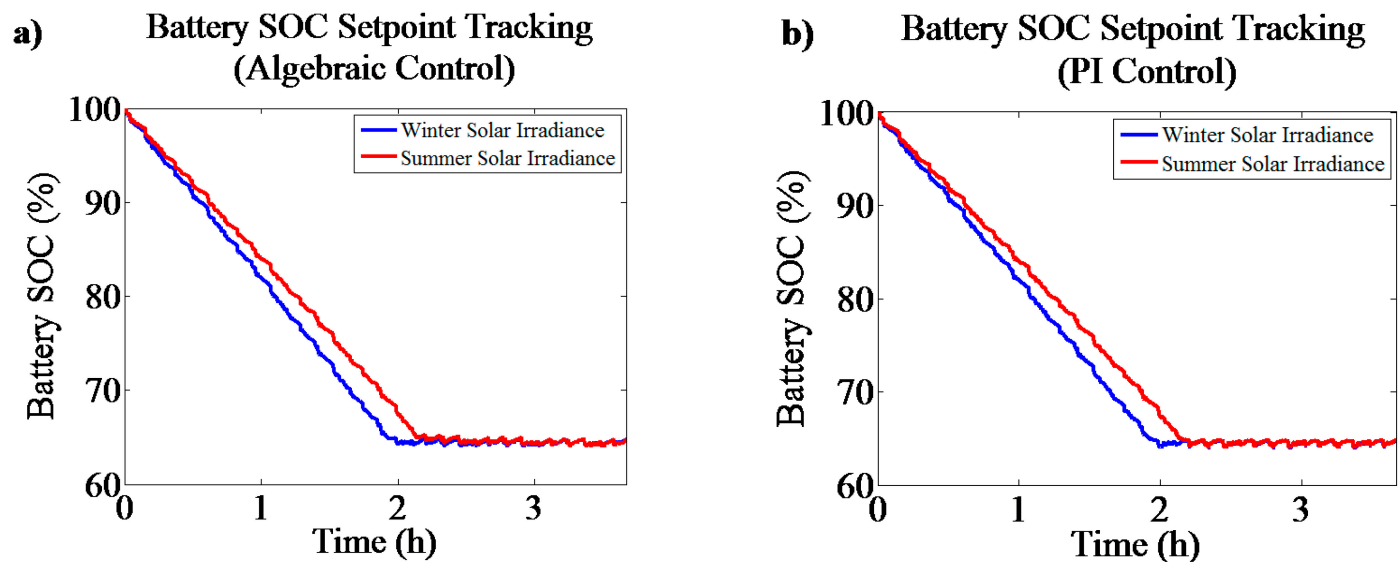

Figure 7. Battery state of charge of the PV/fuel cell/battery bus operations under standard conditions: Simulation results using (a) algebraic control and (b) PI control. Each control strategy is effective in maintaining the battery SOC close to the desired $65 \%$ for both summer and winter solar irradiance profiles.

The simulation results (Figures 6 and 7) show that despite the rapid fluctuations in required bus speed and PV power production, $P_{P V}$, the bus is able to meet its power demands and maintain battery SOC at 
$65 \%$ reasonably well under typical conditions during typical summer and winter operation, using either control strategy.

As expected, observe that regardless of control strategy, the addition of a PV array to the fuel cell/battery bus decreases the amount of hydrogen required by the fuel cell (Figure 8). More specifically, for this particular system, the introduction of supplemental PV power reduces hydrogen consumption by approximately $5 \%$ in the winter and approximately $25 \%$ in the summer, regardless of control strategy.
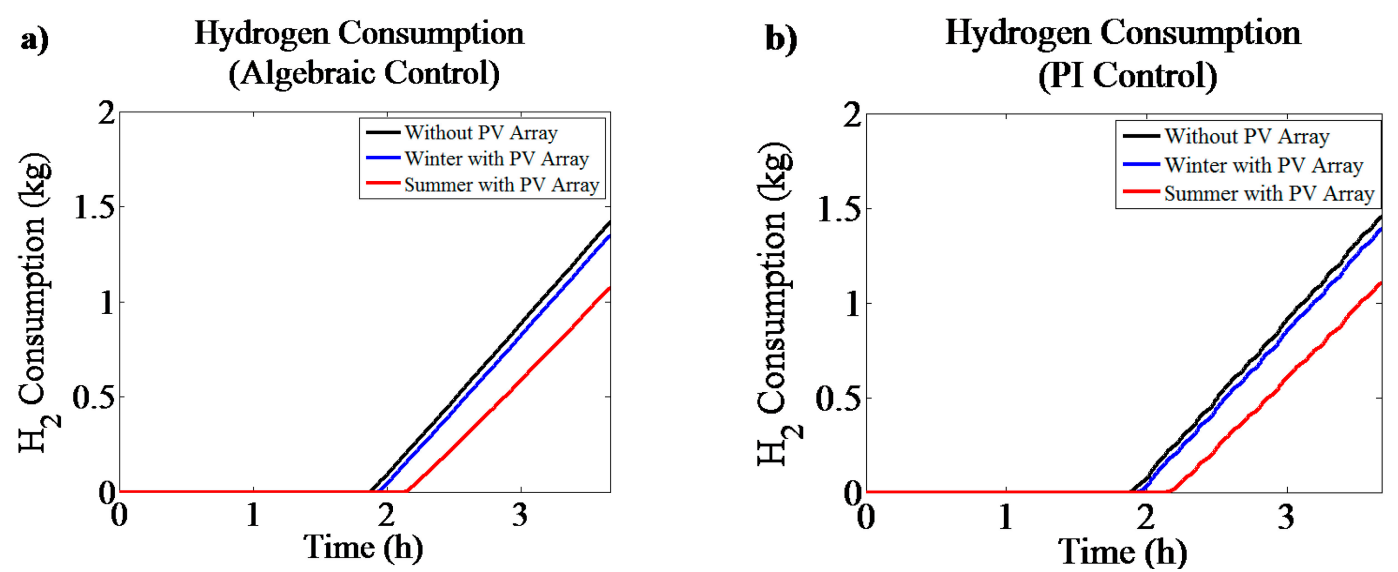

Figure 8. Hydrogen consumption profile of the PV/fuel cell/battery bus operation under standard conditions: Simulation results using (a) algebraic control and (b) PI control. While the bus consumption of hydrogen is approximately the same under each control strategy, the addition of a PV array reduces hydrogen consumption by $5 \%$ during the winter, and $25 \%$ in the summer.

\subsection{Sudden Changes in Cloud Cover}

To evaluate the performance of the control strategies during sudden changes in cloud cover, the bus operation is simulated using constant bus speed $(20 \mathrm{mph})$, constant ambient temperature $(301.24 \mathrm{~K})$, and the idealized solar irradiance profile in Figure 9, over the indicated period. The solar irradiance profile consists of three 30-min intervals when solar irradiance is decreased instantaneously from $1000 \mathrm{~W} / \mathrm{m}^{2}$ to $200 \mathrm{~W} / \mathrm{m}^{2}$ and then returned to $1000 \mathrm{~W} / \mathrm{m}^{2}$. The decrease from $1000 \mathrm{~W} / \mathrm{m}^{2}$ to $200 \mathrm{~W} / \mathrm{m}^{2}$ and subsequent increase from $200 \mathrm{~W} / \mathrm{m}^{2}$ to $1000 \mathrm{~W} / \mathrm{m}^{2}$ simulate instantaneous increase and decrease in cloud cover, respectively.

Figure 10 shows the simulation results of bus operation under these conditions. Figure 10a shows that despite the instantaneous changes to $P_{P V}$ as a result of the simulated cloud cover, both control strategies enable the bus to meet its power demands well enough for practical purposes, with settling times of less than one second after each perturbation. However, magnifying Figure 10a at the moment of sudden change in cloud cover reveals that under PI control, the bus meets its power demands better (if only slightly) than under algebraic control. Additionally, under the algebraic and PI control strategies, the bus maintained battery SOC at 65\% (Figure 10b) and consumed approximately the same amount of hydrogen in doing so (Figure 10c). Our results suggest that the bus is able to cope quite well with sudden changes in cloud cover, and that overall system performance is nearly identical under algebraic or PI control. 


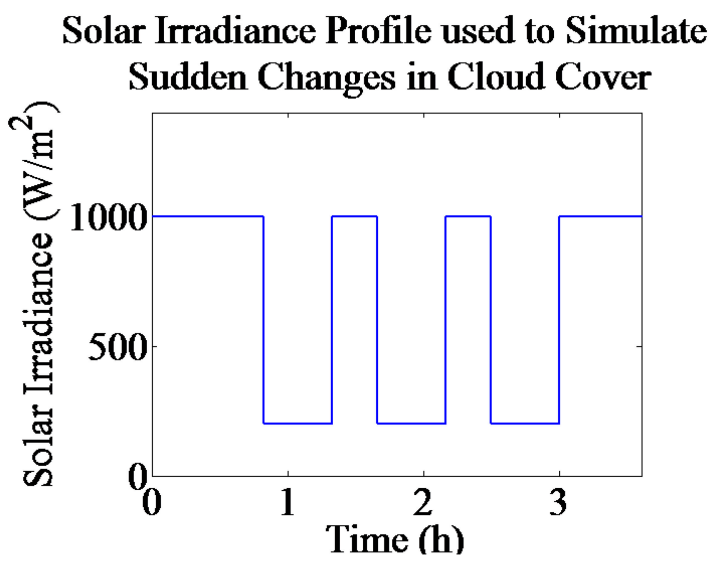

Figure 9. Idealized solar irradiance profile used to simulate how sudden changes in cloud cover affect bus operation with a roof-installed PV array. Solar irradiance is instantaneously decreased from $1000 \mathrm{~W} / \mathrm{m}^{2}$ to $200 \mathrm{~W} / \mathrm{m}^{2}$ three times for 30-min intervals during the $3: 40$ simulation of bus operation.

a) Total Power Demand Setpoint Tracking During Simulated Sudden Cloud Cover
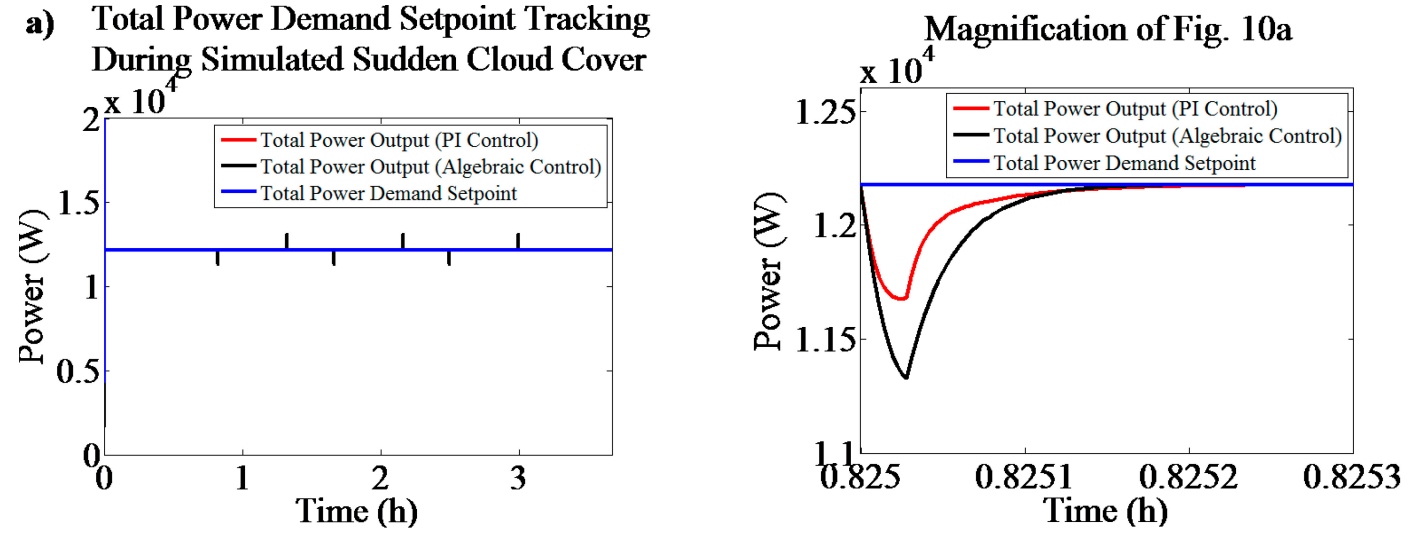

b) Battery SOC Setpoint Tracking

During Simulated Sudden Cloud Cover

c) Hydrogen Consumption
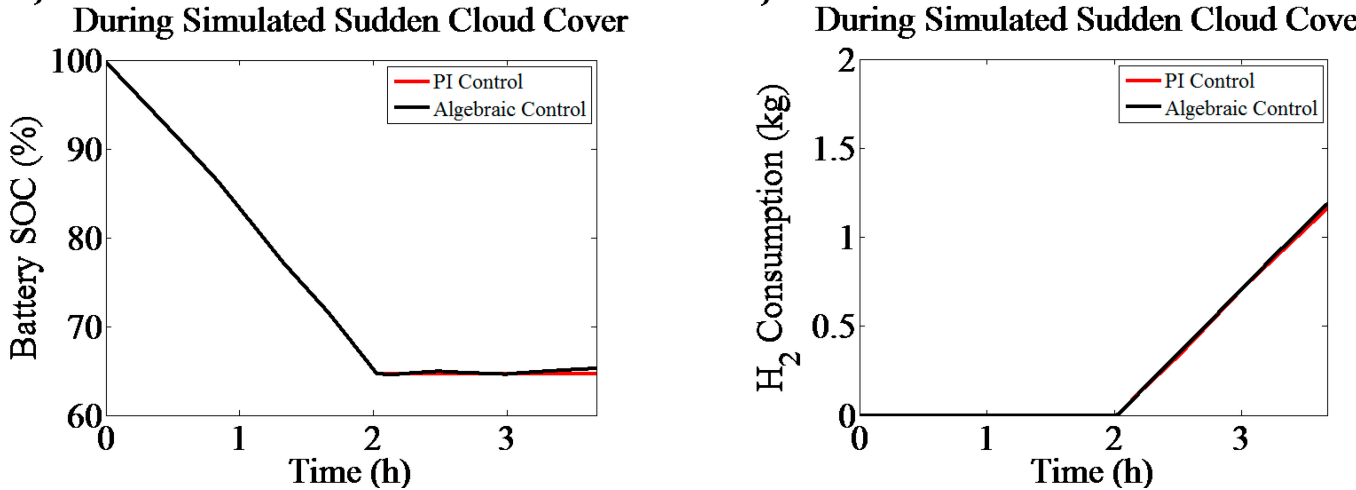

Figure 10. Simulation results of bus operation under sudden changes in cloud cover: (a) Total power demand set point tracking, along with a magnified plot illustrating details; (b) battery SOC set-point tracking; and (c) hydrogen consumption profile. The bus is able to meet its power demands under algebraic and PI control reasonably well despite abrupt, large changes in solar irradiance. Performance in meeting power demands is slightly better under PI control than under algebraic control. The bus is able to maintain battery SOC at $65 \%$ while consuming approximately the same amount of hydrogen under both control strategies. 


\subsection{Sustained Increases in Bus Speed}

How the control strategies perform under sustained increases in bus speed is evaluated by simulating bus operation using the idealized bus speed profile in Figure 11, under conditions of constant solar irradiance $\left(700 \mathrm{~W} / \mathrm{m}^{2}\right)$, constant ambient temperature $(301.24 \mathrm{~K})$. The bus speed profile consists of two separate periods where bus speed is increased from $20 \mathrm{mph}$ to $45 \mathrm{mph}$ (the maximum bus speed) for $30 \mathrm{~min}$ and then decreased from $45 \mathrm{mph}$ to $20 \mathrm{mph}$. Although such a speed profile is not characteristic of a typical bus shuttle run, such conditions may arise in reality should the bus need to remain at maximum speed for an extended period of time, for example, in order to avoid a potential hazard.

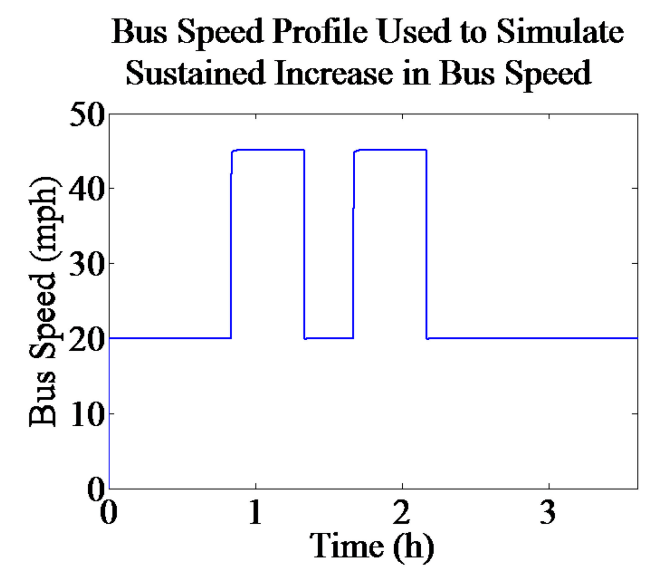

Figure 11. Idealized bus speed profile used to simulate bus operation with a roof-installed PV array. The profile contains two, 30-min periods where bus speed is increased from $20 \mathrm{mph}$ to $45 \mathrm{mph}$ (the maximum bus speed) and subsequently decreased to $20 \mathrm{mph}$.

Figure 12 shows the simulation results. Observe that under sustained increases in bus speed, both control strategies enabled the bus to meet power demands well enough for practical purposes (Figure 12a). However, a magnification of Figure 12a during the first transition from $20 \mathrm{mph}$ to $45 \mathrm{mph}$ shows that total power demand set point tracking performance is slightly better under PI control. As shown in Figure 12b, the bus is unable to maintain battery SOC at $65 \%$ when the bus velocity is increased to $45 \mathrm{mph}$ under either control strategy, because the battery discharge power required to maintain a $45 \mathrm{mph}$ speed exceeds the sum of $P_{P V}$ and maximum fuel cell power. Each time the bus speed is reduced to $20 \mathrm{mph}$ after remaining at $45 \mathrm{mph}$ for $30 \mathrm{~min}$, battery SOC returns to its desired value of $65 \%$ under PI control while under algebraic control, battery SOC overshoots and never quite returns to the desired $65 \%$. The overshoot is the consequence of the drastic increase in $P_{\text {avg }}$ which occurs when the bus reaches its maximum speed for $30 \mathrm{~min}$, causing algebraic controller 2 to produce a value of

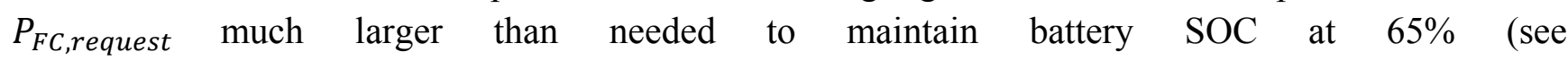
Equations (3a) and (3b)). Additionally, the overestimation of $P_{F C \text {,request }}$ by algebraic controller 2 in this case causes $5 \%$ more hydrogen to be consumed than is needed to maintain the battery SOC at $65 \%$ (Figure 12c). Consequently, when the bus is subjected to sustained increases in bus speed, the PI control strategy has two advantages over the algebraic control strategy: better battery SOC set point tracking and lower hydrogen consumption. 
a) Total Power Demand Setpoint Tracking During Simulated Sustained Increase in Bus Speed

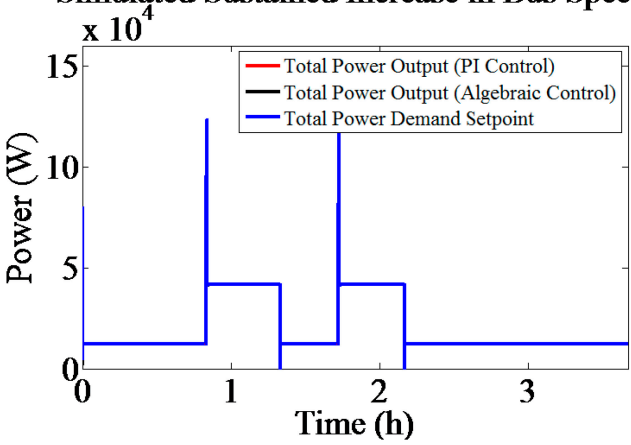

b) Battery SOC Setpoint Tracking During Simulated Sustained Increase in Bus Speed
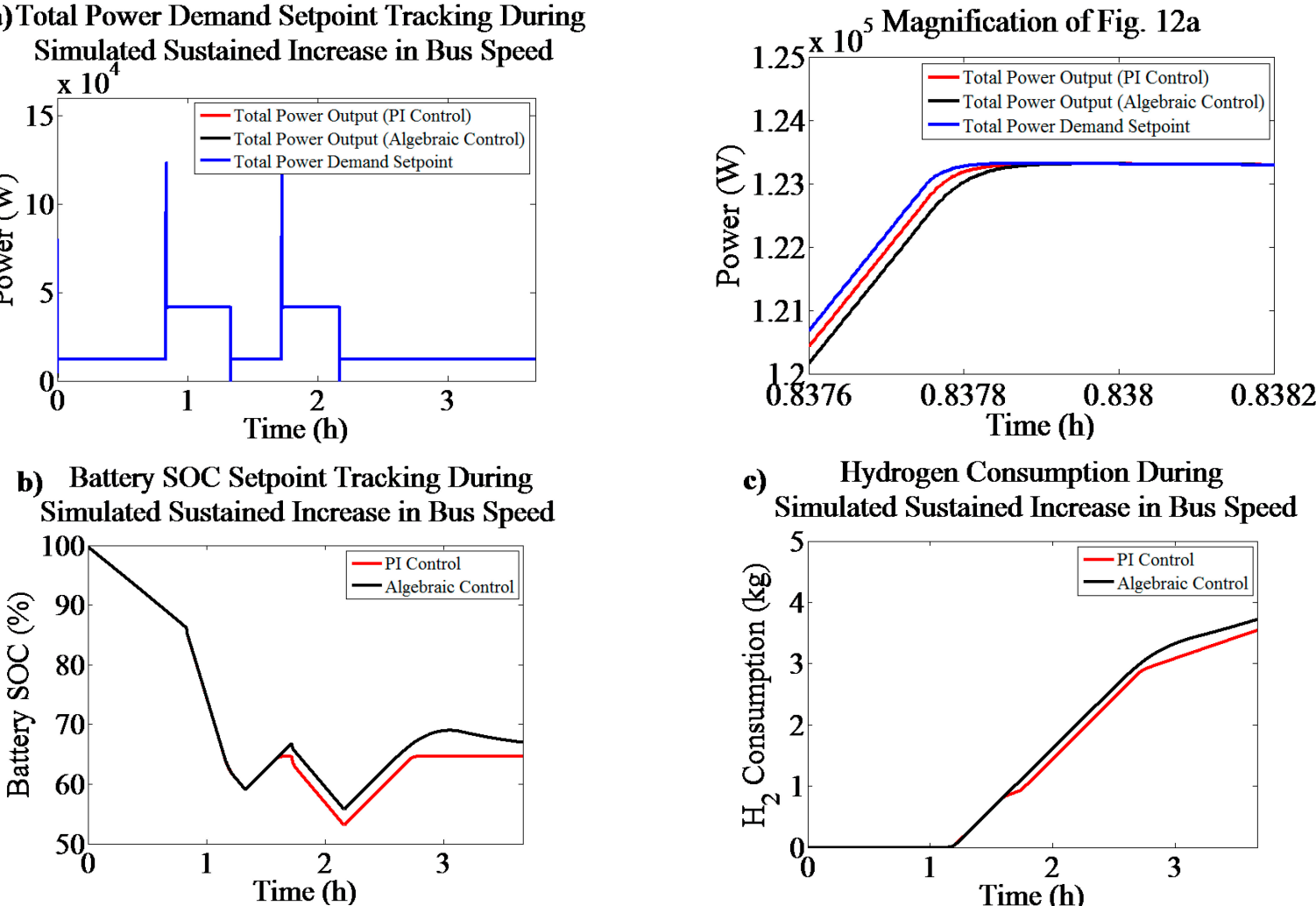

c) Hydrogen Consumption During

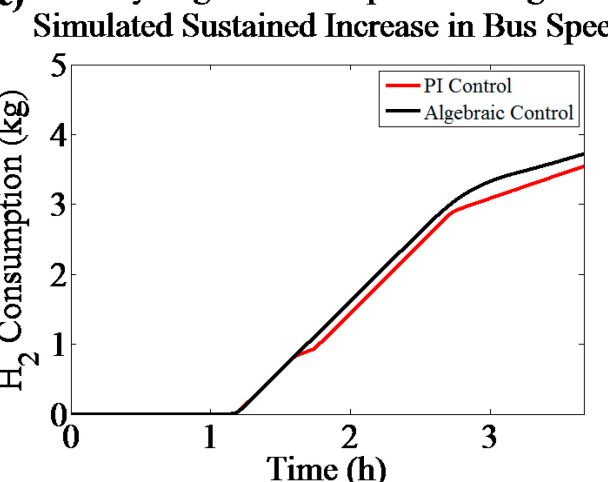

Figure 12. Simulation results of bus operation under sustained increases in bus speed: (a) total power demand set point tracking, along with a magnified plot illustrating details; (b) battery SOC set point tracking; and (c) hydrogen consumption profile. The bus is able to meet its power demands under algebraic and PI control reasonably well despite abrupt large changes in bus speed, but performance in meeting power demand is slightly better with PI control. The bus is able to maintain battery SOC at $65 \%$ with PI control; with algebraic control battery, SOC overshoots the set point to almost $70 \%$. Consequently, under PI control the bus consumed 5\% less hydrogen than under algebraic control.

\section{Economic Analysis}

The economic viability of the PV array modification envisioned in this paper is evaluated using Equation (1) to determine return on investment (ROI) for a range of feasible values for $G_{T, a v g}$ $\left(300 \mathrm{~W} / \mathrm{m}^{2}, 500 \mathrm{~W} / \mathrm{m}^{2}\right.$, and $\left.700 \mathrm{~W} / \mathrm{m}^{2}\right), S_{P V}\left(5 \mathrm{~m}^{2}-50 \mathrm{~m}^{2}\right)$, and $\eta_{P V}(5 \%-50 \%)$, and under the following stipulations:

(1) The total cost (the sum of capital, shipping, and installation costs) of the PV array is $\$ 4810$ $($ Capital cost $=\$ 475$ per PV module, shipping cost $=\$ 60$, and installation cost $=25 \%$ of module cost).

(2) The PV array costs $\$ 1775$ after deducting federal (30\% of total installed costs) and Delaware state tax incentives $(\$ 0.45 / \mathrm{W}$-rated- $\$ 0.90 / \mathrm{W}$-rated, but average of $\$ 0.675 / \mathrm{W}$-rated was used in this work) $[27,28]$.

(3) Cost of hydrogen remains constant at $\$ 3.43 / \mathrm{kg}[29]$.

(4) The bus operates only on $60 \%$ of the days in a year (from average bus availability reported for fuel cell hybrid shuttle buses in 2014; [30]). 
(5) The bus's operational lifetime is 12 years (DOE 2016 target, [30]).

(6) The battery is fully charged at the start of each shuttle run.

(7) The bus operates under PI control.
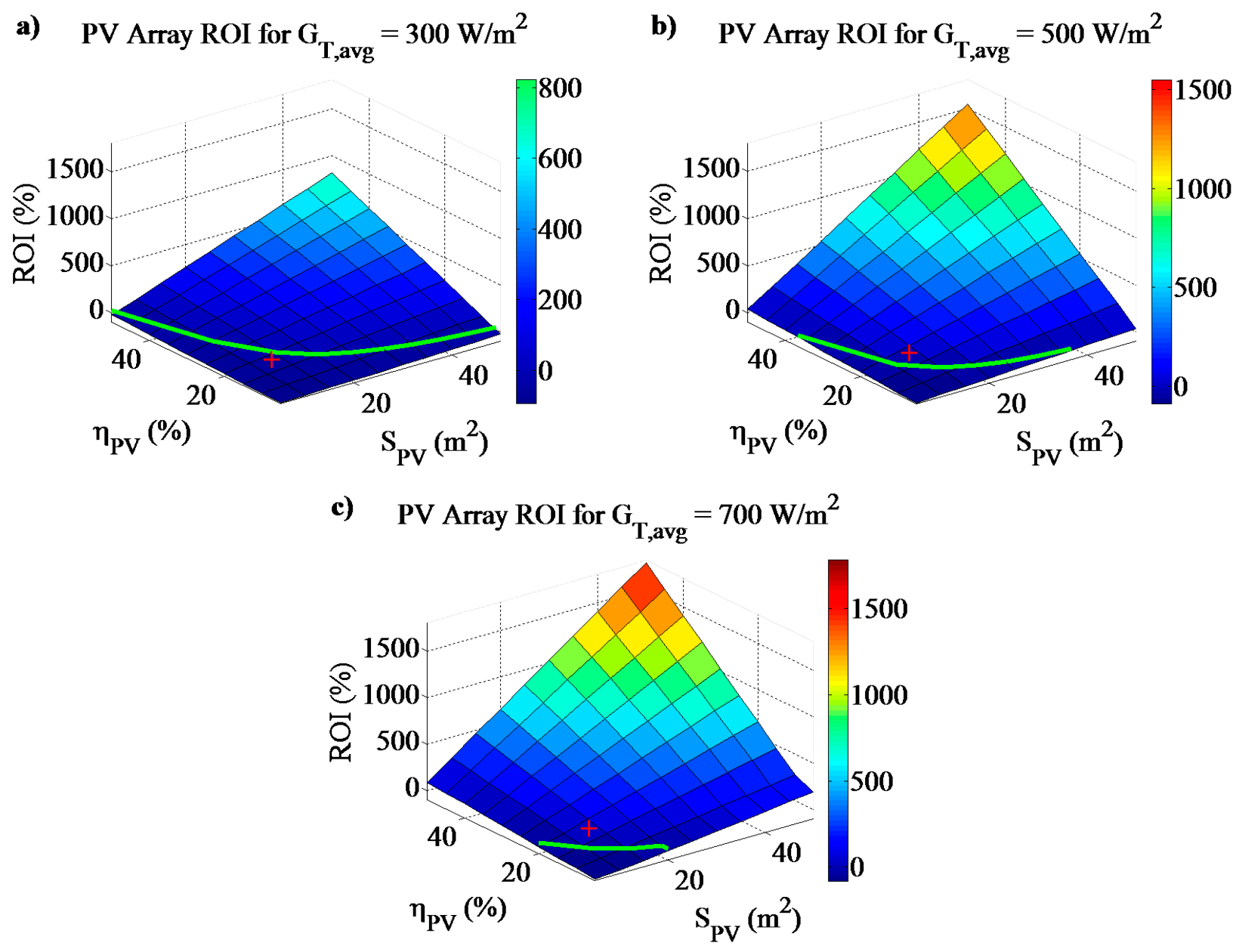

Figure 13. Plots of return on investment (ROI) as a function of PV efficiency $\left(\eta_{P V}\right)$ and PV surface area $\left(S_{P V}\right)$ for three different values of average solar irradiance $\left(G_{T, a v g}\right)$ during bus operation: (a) $300 \mathrm{~W} / \mathrm{m}^{2}$; (b) $500 \mathrm{~W} / \mathrm{m}^{2}$; and (c) $700 \mathrm{~W} / \mathrm{m}^{2}$. The green line in each figure represents the intersection between the ROI $=0 \%$ plane and the ROI surface plot. The red plus sign in each figure represents the characteristics of the PV array used in this work $\left(\eta_{P V}=18.3 \%\right.$ and $\left.S_{P V}=13.12 \mathrm{~m}^{2}\right)$. For such a PV array, when $G_{T, a v g}=300 \mathrm{~W} / \mathrm{m}^{2}$ the ROI is $-20 \%$; when $G_{T, a v g}=500 \mathrm{~W} / \mathrm{m}^{2}$ and $700 \mathrm{~W} / \mathrm{m}^{2}$ the ROI is $30 \%$ and $80 \%$, respectively.

Figure 13 shows PV array ROI as a function of PV array efficiency $\left(\eta_{P V}\right)$ and size $\left(S_{P V}\right)$ for three different values of average solar irradiance $\left(G_{T, a v g}\right)$ during bus operation. In Figure 13a, when $G_{T, \text { avg }}=300 \mathrm{~W} / \mathrm{m}^{2}$-indicative of geographic locations consistently deprived of intense solar radiation - the ROI for the PV array used in this paper (indicated by the red plus sign) is approximately $-20 \%$ (corresponding to a relatively small loss of $\sim \$ 370$ over the bus lifetime). Consequently, in geographical regions where $G_{T, a v g} \leq 300 \mathrm{~W} / \mathrm{m}^{2}$, retrofitting the fuel cell/battery bus with the PV array described here will lead to slight but still negative returns on the investment, so long as 
$C_{P V}=\$ 1775$. On the other hand, Figure 13b indicates that when $G_{T, a v g}=500 \mathrm{~W} / \mathrm{m}^{2}$ — consistent with geographic locations similar to Newark, DE - the PV array described here yields a 30\% ROI (a slight, but nonetheless positive, $\$ 550$ profit over the bus lifetime). Finally, as one might expect, when $G_{T, a v g}=700 \mathrm{~W} / \mathrm{m}^{2}$ - indicative of geographic locations with high year-round exposure to sunlightFigure 13c shows that the increased solar irradiance translates to the PV array addition generating improved profits. More specifically, under such conditions, the ROI from installing the PV array is $80 \%$ (an improved $\sim \$ 1,470$ profit over the bus lifetime). Consequently, we recommend implementing the $\mathrm{PV} /$ fuel cell/battery bus described in this study in Newark, DE and in other geographic locations with average solar irradiance greater than $500 \mathrm{~W} / \mathrm{m}^{2}$ during bus operation.

\section{Summary and Conclusions}

In this paper, we have discussed the design and operation of a PV/fuel cell/battery bus. We evaluated the performance under algebraic and PI control via simulation of bus operation (augmented with real data) under various conditions: typical summer and winter conditions; sudden changes in cloud cover; and intermittent periods of sustained increase in bus speed. We showed that under typical operating conditions during summer and winter, the PV/fuel cell/battery HRES is able to meet bus power demands, and maintain the battery SOC at $65 \%$, with either control strategy. Furthermore, simulation results indicate that the addition of a PV array to the existing fuel cell/battery bus can reduce hydrogen consumption by as much $10 \%-35 \%$, under typical operating conditions. During periods of sudden changes in cloud cover, the bus is able to meet its power demands and maintain battery SOC at $65 \%$ while consuming approximately the same amount of hydrogen under both control strategies. However, during periods of sustained increase in bus speed, the PI control strategy is more effective than the algebraic control strategy in maintaining battery SOC at $65 \%$, while also consuming $5 \%$ less hydrogen. Consequently, standard PI control is preferred for operating the PV/fuel cell/battery bus.

We evaluated the economic viability of the proposed addition of a PV array to the fuel cell bus by determining the values of $G_{T, a v g}, S_{P V}$, and $\eta_{P V}$ required for a positive ROI. For values of $G_{T, \text { avg }} \leq 300 \mathrm{~W} / \mathrm{m}^{2}$, the ROI for the PV array design employed in this study $\left(S_{P V}=13.12 \mathrm{~m}^{2}\right.$ and $\eta_{P V}=18.3 \%$ ) is approximately $-20 \%$, implying that the addition of a PV array to the fuel cell/battery bus does not quite pay for itself in locations with such low exposure to sunlight during the bus operating hours (between $12 \mathrm{pm}$ and 3:40 pm). However, for values of $G_{T, a v g} \geq 500 \mathrm{~W} / \mathrm{m}^{2}$, the ROI is positive $\left(30 \%\right.$ ROI for $G_{T, a v g}=500 \mathrm{~W} / \mathrm{m}^{2}$, and $80 \%$ ROI for $\left.G_{T, \text { avg }}=700 \mathrm{~W} / \mathrm{m}^{2}\right)$. Because the bus is likely to be exposed to an average of at least $500 \mathrm{~W} / \mathrm{m}^{2}$ of solar irradiance during operation in Newark, DE, we conclude that the addition of a roof installed PV array to the fuel cell/battery bus as investigated in this study is economically viable and can be implemented successfully at the University of Delaware. In general, under conditions where $G_{T, a v g} \geq 500 \mathrm{~W} / \mathrm{m}^{2}$, we expect that the PV array modification to the fuel cell/battery bus will pay for itself while producing zero harmful emissions.

\section{Acknowledgments}

We are grateful to Doug Brunner for assistance in acquiring data from the fuel cell/battery bus currently operating at the University of Delaware, and to Jingliang Zhang for his assistance with the original fuel cell/battery bus simulation. 


\section{Author Contributions}

A.K.P. and P.B. developed the original fuel cell/battery bus model; B.A.O. conceived the research concept; Z.S.W. developed the full model, collected the data; Z.S.W., P.B., A.K.P., and B.A.O. assisted in analyzing the data; Z.S.W. and B.A.O. wrote the manuscript.

\section{Conflicts of Interest}

The authors declare no conflict of interest.

\section{Nomenclature}

$\boldsymbol{A}_{\text {bus }}$, Bus availability [frac.]; $\boldsymbol{\beta}$, proportionality constant in the "algebraic control" equation [W/\%]; $\boldsymbol{C}_{\boldsymbol{H}_{2}}$, cost of hydrogen [\$ $\left.\mathrm{kg}^{-1}\right] ; \boldsymbol{C}_{\boldsymbol{P V}}$, cost of the PV array [\$]; $\boldsymbol{\varepsilon}_{\mathbf{1}}$, feedback error in control loop 1, the difference between the total power set point and the combined battery and photovoltaic power [W]; $\boldsymbol{\varepsilon}_{\mathbf{2}}$, feedback error in control loop 2, the difference between the battery SOC set point and the measured battery SOC $[\%] ; \boldsymbol{G}_{\boldsymbol{T}}$, solar irradiance $\left[\mathrm{W} \cdot \mathrm{m}^{-2}\right] ; \boldsymbol{G}_{\boldsymbol{T}, \boldsymbol{a v g}}$, average solar irradiance during bus operation $\left[\mathrm{W} \cdot \mathrm{m}^{-2}\right] ; \boldsymbol{\eta}_{\boldsymbol{P V}}, \mathrm{PV}$ array efficiency $[\%] ; \boldsymbol{K}_{\boldsymbol{i}}$, integral gain of the total power PI controller $\left[\mathrm{s}^{-1}\right]$; $\boldsymbol{K}_{\boldsymbol{p} \mathbf{1}}$, proportional gain of the total power PI controller [N/A]; $\boldsymbol{K}_{\boldsymbol{p} \mathbf{2}}$, proportional gain of the battery SOC controller $\left[\mathrm{kg} \cdot \mathrm{s}^{-1 . \%}\right] ; \boldsymbol{L}_{\boldsymbol{b u s}}$, bus lifetime [years]; $\boldsymbol{M}_{\boldsymbol{H}_{2}, \boldsymbol{P V}}$, mass of hydrogen consumed per day by the bus with a PV array $[\mathrm{kg}] ; \boldsymbol{M}_{\boldsymbol{H}_{2}, \boldsymbol{n o} \boldsymbol{P V}}$, mass of hydrogen consumed per day by the bus without a PV array $[\mathrm{kg}] ; \boldsymbol{P}_{\text {accessory }}$, accessory power demand on the bus [W]; $\boldsymbol{P}_{\boldsymbol{a v g}}$, one-hour time average net battery power [W]; $\boldsymbol{P}_{\boldsymbol{b a t} \text {, } \boldsymbol{c h}}$, combined power from the fuel cell, regenerative braking, and PV array, used to charge the battery [W]; $\boldsymbol{P}_{\text {batt,request }}$, battery power requested by the controller in order to meet residual bus power demand unmet by the PV array [W]; $\boldsymbol{P}_{\boldsymbol{b a t} \text {, dis }}$, battery discharge power [W]; $\boldsymbol{P}_{\boldsymbol{F} \boldsymbol{C}, \boldsymbol{n e t}}$, net fuel cell power output $[\mathrm{W}] ; \boldsymbol{P}_{\boldsymbol{F C} \text {,request }}$, fuel cell power requested by the controller in order to maintain the battery SOC [W] at the desired value; $\boldsymbol{P}_{\boldsymbol{P V}}$, power produced by the PV array [W]; $\boldsymbol{P}_{\boldsymbol{P V} \text {,excess }}$, excess PV power remaining after meeting bus power demand [W]; $\boldsymbol{P}_{\boldsymbol{R} \boldsymbol{B}}$, power produced from regenerative braking $[\mathrm{W}] ; \boldsymbol{P}_{\text {total }}$, total bus power demand (sum of traction and power demands) [W]; $\boldsymbol{P}_{\text {total,m }}$, total system power output [W]; $\boldsymbol{P}_{\text {traction }}$, bus traction power demand [W]; $\boldsymbol{S O} \boldsymbol{C}_{\boldsymbol{d}}$, desired battery SOC [\%]; $\boldsymbol{S}_{\boldsymbol{P V}}, \mathrm{PV}$ array size $\left[\mathrm{m}^{2}\right] ; \boldsymbol{S O C}_{\boldsymbol{m}}$, measured battery SOC [\%]; $\boldsymbol{T}_{\boldsymbol{a}}$, ambient temperature $[\mathrm{K}] ; \boldsymbol{V}$, bus velocity $[\mathrm{m} / \mathrm{s}]$.

\section{References}

1. Breakthrough Technologies Institute. 2010 Fuel Cell Technologies Market Report; U.S. Department of Energy: Washington, DC, USA, 2011.

2. Basi, J.; Farquharson, N. PEM Fuel Cells Make a Powerful Case for Small Business Backup; CommScope: Hickory, NC, USA, 2014.

3. Mekhilef, S.; Saidur, R.; Safari, A. Comparative study of different fuel cell technologies. Renew. Sustain. Energy Rev. 2012, 16, 981-989.

4. Kordesch, K.V.; Simader, G.R. Environmental Impact of Fuel Cell Technology. Chem. Rev. 1995, 95, 191-207. 
5. Bubna, P.; Brunner, D.; Gangloff, J.J., Jr.; Advani, S.G.; Prasad, A.K. Analysis, operation and maintenance of a fuel cell/battery series-hybrid bus for urban transit applications. J. Power Sources 2010, 195, 3939-3949.

6. Divya, K.C.; Østergaard, J. Battery energy storage technology for power systems-An overview. Electr. Power Syst. Res. 2009, 79, 511-520.

7. Nelson, R.F. Power requirements for batteries in hybrid electric vehicles. J. Power Sources 2000, 91, 2-26.

8. Bergveld, H.J.; Kruijt, W.S.; Notten, P.H.L. Battery Management Systems: Design by Modelling; Toolenaar, F., Ed.; Springer: Eindhoven, The Netherlands, 2002.

9. Hofman, T.; Steinbuch, M.; van Druten, R.; Serrarens, A. Rule-Based energy management strategies for hybrid vehicles. Int. J. Electr. Hybrid Veh. 2007, 1, doi:10.1504/IJEHV.2007.014448.

10. Baumann, B.M.; Washington, G.; Glenn, B.C.; Rizzoni, G. Mechatronic design and control of hybrid electric vehicles. IEEE/ASME Trans. Mechatron. 2000, 5, 58-72.

11. Won, J.-S.; Won, J.-S.; Langari, R.; Langari, R. Fuzzy torque distribution control for a parallel hybrid vehicle. Expert Syst. 2002, 19, 4-10.

12. Hofman, T. Rule-Based equivalent fuel consumption minimization strategies for hybrid vehicles. In Proceedings of the International Federation of Automatic Control, Seoul, Korea, 6-11 June 2008; Volume 17, pp. 5652-5657.

13. Li, X.; Xu, L.; Hua, J.; Lin, X.; Li, J.; Ouyang, M. Power management strategy for vehicular-applied hybrid fuel cell/battery power system. J. Power Sources 2009, 191, 542-549.

14. Li, C.Y.; Liu, G.P. Optimal fuzzy power control and management of fuel cell/battery hybrid vehicles. J. Power Sources 2009, 192, 525-533.

15. Bernard, J.; Delprat, S.; Guerra, T.M.; Büchi, F.N. Fuel efficient power management strategy for fuel cell hybrid powertrains. Control Eng. Pract. 2010, 18, 408-417.

16. Brahma, A.; Guezennec, Y.; Rizzoni, G. Optimal energy management in series hybrid electric vehicles. In Proceedings of the American Control Conference, Chicago, IL, USA, 29 June 2000; Volume 1, pp. 60-64.

17. Xu, L.; Ouyang, M.; Li, J.; Yang, F. Dynamic Programming Algorithm for minimizing operating cost of a PEM fuel cell vehicle. In Proceedings of the 2012 IEEE International Symposium on Industrial Electronics (ISIE), Hangzhou, China, 28-31 May 2012; pp. 1490-1495.

18. Paganelli, G.; Delprat, S.; Guerra, T.M.; Rimaux, J.; Santin, J.J. Equivalent consumption minimization strategy for parallel hybrid powertrains. In Proceedings of the IEEE 55th Vehicular Technology Conference, 7 May 2002; Volume 4, pp. 2076-2081.

19. Delprat, S.; Lauber, J.; Guerra, T.-M.; Rimaux, J. Control of a parallel hybrid powertrain: Optimal control. Veh. Technol. IEEE Trans. 2004, 53, 872-881.

20. Feroldi, D.; Serra, M.; Riera, J. Energy Management Strategies based on efficiency map for Fuel Cell Hybrid Vehicles. J. Power Sources 2009, 190, 387-401.

21. Musardo, C.; Rizzoni, G.; Guezennec, Y.; Staccia, B. A-ECMS: An Adaptive Algorithm for Hybrid Electric Vehicle Energy Management. Eur. J. Control 2005, 11, 509-524.

22. Simmons, K.; Guezennec, Y.; Onori, S. Modeling and energy management control design for a fuel cell hybrid passenger bus. J. Power Sources 2014, 246, 736-746. 
23. Schell, A.; Peng, H.; Tran, D.; Stamos, E.; Lin, C.C.; Kim, M.J. Modelling and control strategy development for fuel cell electric vehicles. Annu. Rev. Control 2005, 29, 159-168.

24. Bubna, P. Modeling, Simulation and Optimization of Fuel Cell/Battery Hybrid Powertrains. Ph.D. Thesis, University of Delaware, Newark, DE, USA, August 2010.

25. Ro, K.; Rahman, S. Two-Loop controller for maximizing performance of a grid-connected photovoltaic-fuel cell hybrid power plant. IEEE Trans. Energy Convers. 1998, 13, 276-281.

26. Ogunnaike, B.A.; Ray, W.H. Process Dynamics, Modeling, and Control; Oxford University Press: New York, NY, USA, 1994.

27. Federal Incentives/Policies for Renewables and Efficiency-Residential Renewable Energy Tax Credit. Available online: http://www.dsireusa.org/incentives/incentive.cfm?Incentive_Code= US37F\&re $=0 \&$ ee $=0$ (accessed on 2 February 2015).

28. Delaware Incentives/Policies for Renewables and Efficiency_Delaware Electric CooperativeGreen Energy Program Incentives (SRECs). Available online: http://www.dsireusa.org/incentives/ incentive.cfm? Incentive_Code $=$ DE20F $\&$ re $=0 \&$ ee $=0$ (accessed on 2 February 2015).

29. Bourbon, E. Clean Cities Alternative Fuel Price Report; U.S. Department of Energy: Washington, DC, USA, 2014.

30. Eudy, L.; Post, M.; Gikakis, C. Fuel Cell Buses in U. S. Transit Fleets: Current Status 2014; National Renewable Energy Laboratory: Golden, CO, USA.

(C) 2015 by the authors; licensee MDPI, Basel, Switzerland. This article is an open access article distributed under the terms and conditions of the Creative Commons Attribution license (http://creativecommons.org/licenses/by/4.0/). 